\title{
The Existence of Gorontalo Muhammadiyah University in Increasing the Income of the East Pentadio Village Community
}

\author{
Joice Machmud $^{1}$, Srihantuti Paramata ${ }^{1}$, Fangki Mobilingo ${ }^{1}$ \\ Email: fangkimobilingo17@gmail.com \\ ${ }^{1}$ Development Economics Study Program, Faculty of Social Sciences, Muhammadiyah \\ University of Gorontalo, Indonesia
}

Received: December 5, 2020

Revised: December 20, 2020

Accepted: December 29, 2020

\begin{abstract}
The purpose of this research was to determine the existence of the Muhammadiyah University of Gorontalo in increasing the income of the people of East Pentadio Village. This research uses a descriptive qualitative research approach, using interview instruments with various informants. The results using Samuelson's theory about the factors that influence income, show that the existence of the Muhammadiyah University of Gorontalo is able to increase the income of the people of East Pentadio Village. However, the current existence of the campus has not been fully utilized by the community in increasing the income of the people of East Pentadio Village. There are still many outsiders who take advantage of the opportunity of the existence of the Muhammadiyah University of Gorontalo by making larger businesses in the campus area so that community businesses that are built simply with little capital experience competition. The low level of education of rural communities makes the business that is built still not optimal and makes the community less creative and innovative in entrepreneurship. This also causes people to easily give up when experiencing losses.
\end{abstract}

Keywords: Increase, People's Income, Institution Role

\section{Introduction}

Economic Development is learning about economic development in a certain region or country that has a developing economy level (Ascani et al., 2012). There are three important elements in the development process, namely change, goals, and potential. Through these changes, it is hoped that progress that was originally less will become better, so that development goals can be achieved. Building a nation involves many parties, be it the government, the people, community groups in an institution and also the environment (Berkes, 2009; Doh \& Guay, 2006).

Economic development is a process that occurs continuously related to changes in the development of a country or region for the welfare of its population (Awan, 2013; Stimson ET AL., 2006). In addition, it is explained that God also commands humans to work and try to fulfill their needs. Because by working, we show our efforts to get sustenance or income. as ordained by Allah SWT. As the Word of Allah SWT in QS. At-Taubah [9]:105

And say: "Work you, then Allah and His Messenger and the believers will see your work, and you will be returned to (Allah) Who knows the unseen and the real, then He will inform you of what is you have done.

The Prophet Muhammad recommended that a person work and be an entrepreneur so that he can live independently, without depending on the gifts of others. The Prophet himself had worked as a cattle herder and a trader. By working, a person can have their own income and

Copyright @ 2020, Journal of Asian Multicultural Research for Social Sciences Study, Under the license CC BY-SA 4.0 
not beg from others. People who like to beg are not only miserable in this world but on the Day of Resurrection there will be no flesh on their faces. It is explained in the hadith below: "Indeed, Allah loves servants who work and are skilled. Whoever struggles to earn a living for his family is like a mujahid in the way of Allah." (Hadith narrated by Ahmad)

The above hadith shows that working or trying is a very noble act in Islamic teachings. In working, it is not only to fulfill daily needs but also to maintain self-respect and human dignity which should be upheld. People who work or try to earn income with their energy. In Islam, people like this are categorized as jihad fi sabilillah.

To build an economy in a certain region or country, we must be creative in building the economy, so that the development we do is in accordance with the expectations of the community and based on the rules and laws that apply in a country (Needham et al., 2018; Pade et al., 2008). Article 2 of Law NO 24 of 2019 concerning the creative economy explains that the implementation of the creative economy must be based on Pancasila, the 1945 Constitution of the Republic of Indonesia, the Unitary State of the Republic of Indonesia, and Bhineka Tunggal Ika. So we must be able to be creative people in economic development, especially in increasing people's income in certain regions and countries.

Income "Revenue is the gross inflow of economic benefits arising from the normal activities of the entity during a period if the inflow results in an increase in equity that does not come from investment contributions". Research by Arys Suharyanto Universities are one of the educational institutions that play an important role in sustainable national development. One of the important aspects of national development is the development of human resources to create a productive workforce in an effort to combine economic growth and economic structure with equitable development. Currently, universities in Indonesia are growing, both in quantity and quality. So that higher education is needed in this day and age, not only to educate but to train one's abilities or skills. So that creative ideas and positive updates will be created in various aspects to improve quality human resources.

Muhammadiyah University of Gorontalo is an enlightenment campus located in Gorontalo Province. Muhammadiyah University of Gorontalo Operations. based on the operational Decree (SK) of the University of Muhammadiyah Gorontalo (UMG) from the Minister of National Education of the Republic of Indonesia Number 98/D/0/2008. The study programs that will be opened are Information, Geography, Agribusiness, Animal Husbandry, Aquaculture, Nursing, Educator Midwives, Development Economics, State Administration, English Literature, and Arabic Literature. The existence of Muhammadiyah University of Gorontalo in Pentadio Timur Village, Telaga Biru District, has contributed to supporting the local community's economy, such as boarding house entrepreneurs, photocopying businesses, drinking water depots, food traders and entrepreneurs.

The people of East Pentadio Village are considered to have not been able to take advantage of the opportunity of the existence of the Muhammadiyah University of Gorontalo to increase their income. Some of the businesses are only utilized by people outside the village of East Pentadio. In addition, community businesses in the East Pentadio Village, around the Muhammadiyah University of Gorontalo, are still less competitive with businesses built by people outside the village, for example, the simple boarding house business for the East Pentadio village community is experiencing competition with the businesses of people outside the village in the form of boarding houses. terraced, complete and luxurious facilities so that it attracts the attention of consumers.

Seeing the fact that the presence of the Muhammadiyah Gorontalo campus is seen to be able to affect people's income, the level of community welfare, the quality of human resources, and

Copyright $@$ (2020, Journal of Asian Multicultural Research for Economy and Management Study, Under the license CC BY-SA 4.0 
increased consumption power. For example, many students from outside need a place to live while attending lectures, students who need vehicles for campus, students who need food ingredients and for daily needs and many other needs that have become human nature to fulfill them.

Based on the background and problem identification, this research is focused on whether the existence of the Muhammadiyah University of Gorontalo is able to increase the income of the East Pentadio village community. The purpose of this study was to determine the existence of the Muhammadiyah University of Gorontalo in increasing the income of the people of East Pentadio Village.

\section{Methods}

This study uses a descriptive type of research with a qualitative approach. Descriptive research is research that provides an overview of an object under study through sample or population data. According to Sugiyono (2012 , p.8). Qualitative research is a method used to see the natural state of objects, while descriptive qualitative research is a research method that outlines opinions based on research questions, then analyzed according to the behavior of respondents, reduced, triangulated, concluded and verified. Informants in this study consisted of , the village head and several business actors in the east pentadio village such as food stall entrepreneurs, photocopy entrepreneurs, drinking water depot entrepreneurs, boarding house entrepreneurs and bentor craftsmen.

Sources of data in this case include: Primary data, namely data obtained through direct observation and interviews with objects and guided by a list of questions that have been prepared. In this study, the sources of data are business actors in East Pentadio Village such as: Head of East Pentadio Village, boarding house business actors, drinking water depot business actors, photocopying business actors, food traders business actors and bentor service actors. namely data in the form of documents or archives in the form of books, notes, recordings, documentation, and others relevant to the research. In qualitative data analysis there are three flow of activities that occur simultaneously. Activities in data analysis are:

Data condensation refers to the process of selecting, simplifying, abstracting and transforming data that approximates all parts of written field notes, interview transcripts, documents, and other empirical materials. Data reduction and presentation of the results are carried out continuously during the data collection process, then temporary conclusions are drawn from the results.

Presentation of data can be in the form of writing, pictures, tables and graphs. The purpose of presenting data is to combine information so that it can provide an overview of the situation that occurs. In this case, so that researchers do not experience difficulties in mastering information properly and thoroughly and also certain parts of the research results. Therefore, researchers must create narratives, graphs or matrices to facilitate mastery of the data or information. In this way, researchers can stay in control of the data and not sink into conclusions that can be boring. This is done because the data that is compiled poorly can influence the researcher in drawing impartial conclusions and in acting recklessly, and not fundamentally. Regarding data display, it must be recognized as part of data analysis.

Conclusions are drawn during the course of the study, as is the case with the data reduction process, after the data has been collected adequately, temporary conclusions can be obtained, and after the data is completely complete, final conclusions can be obtained. Starting from the beginning of the study, researchers always want to try to find the meaning of the data collected. Therefore it is necessary to find themes, patterns, similarities, relationships, hypotheses, things that often arise and others. Initially the conclusions obtained were vague, tentative and 
doubtful, but with increasing data, both from observations and interviews and from the overall data obtained from the research. Therefore, these conclusions must be clarified and verified during the course of the study

\section{Results and Discussion}

The results of the study using research instruments based on the theory of Samuelson in his book Microeconomics 2003 page 205 are as follows:

The existence of the Muhammadiyah University of Gorontalo is seen as being able to provide business opportunities to the community, many small businesses have begun to be built in the campus area. It is clear that its existence is able to provide business opportunities for the surrounding community. It is also known from the results of interviews with several sources, who said that the campus opened up business opportunities for the people of the East Pentadio village, many people started to build businesses around the campus both inside and outside the campus. However, for now, the condition of the campus is still not optimal in increasing people's income, unlike the beginning of its existence, when the campus still had many students so that community efforts were increasingly advanced. So that the community hopes that with the current campus construction, which has begun to improve, the number of students will also increase.

\section{Market Conditions}

The condition of the sales market is seen not only used by the people of the East Pentadio village but the people outside the village who have started to build businesses around the Muhammadiyah University of Gorontalo. This is also known based on the results of interviews with several informants who said that, many people from outside the village of East Pentadio have started to build businesses in the campus area, even their businesses are bigger, have complete facilities, and are strategically located. So that the efforts of the people of the East Pentadio village are still less competitive with those of the people outside the village.

\section{Capital}

The people of the eastern pentadio village are seen with the existence of the Muhammadiyah University of Gorontalo, many people have learned entrepreneurship, and have even become community professions. Approximately $50 \%$ of the people are already capable of entrepreneurship. The capital for boarding houses is approximately 60 million, the capital for the food stall business is approximately 10 million, the capital for the drinking water depot business is approximately 20 million, the photocopying business capital is approximately 15 million. And the business capital as a bentor is approximately 20 million. To return the capital, people always set aside income to return the capital.

\section{Operational Conditions}

Regarding the village government's policy, it never makes it difficult for the community to do entrepreneurship, while spending is only for a few businesses that are on the side of the road (Bornstein, 2007). And for people who build businesses around campus or in their respective homes, this is certainly not a problem. The condition of the average operational costs that are issued for community businesses are the cost of electricity, water, taxes and basic business materials.

\section{Other Influencing Factors}

The level of education more or less affects the community in entrepreneurship. Because people with low education do not really have the ability or expertise, are not creative and quickly give up when they experience a loss. So that the name of education is needed because some people

Copyright (C) 2020, Journal of Asian Multicultural Research for Economy and Management Study, 
with low education only build businesses carelessly. There are only a few business actors in the village of Pentadio Timur, the highest education level up to junior high and high school levels are graduates, because according to the community education is not too important, what matters is capital and courage. So that awareness in taking education is still lacking among the community.

\section{Conclusion}

The existence of the Muhammadiyah University of Gorontalo is able to increase the income of the people of East Pentadio Village. However, the current condition of the existence of the campus has not been utilized optimally by the community in increasing people's income, due to the pandemic condition and the declining number of students. The increase in income is visible but not significant. This condition makes the people of East Pentadio Village still not take advantage of business opportunities as well as possible. Many outsiders take advantage of the opportunity of the existence of the Muhammadiyah University of Gorontalo by making bigger businesses in the campus area so that simple community businesses are still less competitive. The low level of public education is the highest at the elementary and junior high school levels, this makes the businesses that are built less creative and innovative in entrepreneurship. This also causes people to quickly despair when experiencing losses. It is better for the community to take more advantage of business opportunities with the existence of a campus, with the use of business opportunities, the income of the East Pentadio village community can increase. It is better if the village government pays more attention to the outside community who build businesses in the East Pentadio Village, and to improve the human resource capacity of the East Pentadio Village. The East Pentadio village community should improve the quality of human resources through education.

\section{References}

Ascani, A., Crescenzi, R., \& Iammarino, S. (2012). Regional economic development. A Review, SEARCH WP01/03, 2-26.

Awan, A. G. (2013). Relationship between environment and sustainable economic development: A theoretical approach to environmental problems. International Journal of Asian Social Science, 3(3), 741-761.

Berkes, F. (2009). Evolution of co-management: role of knowledge generation, bridging organizations and social learning. Journal of environmental management, 90(5), 1692-1702.

Bornstein, D. (2007). How to change the world: Social entrepreneurs and the power of new ideas. Oxford University Press.

Doh, J. P., \& Guay, T. R. (2006). Corporate social responsibility, public policy, and NGO activism in Europe and the United States: an institutional-stakeholder perspective. Journal of Management studies, 43(1), 47-73.

Needham, B., Buitelaar, E., \& Hartmann, T. (2018). Planning, Law and Economics: The rules we make for using land. Routledge.

Pade, C., Mallinson, B., \& Sewry, D. (2008). An elaboration of critical success factors for rural ICT project sustainability in developing countries: Exploring the Dwesa case. Journal of Information Technology Case and Application Research, 10(4), 32-55.

Stimson, R. J., Stough, R. R., \& Roberts, B. H. (2006). Regional economic development: analysis and planning strategy. Springer Science \& Business Media.

Sugiyono, (2010). Metode Penelitian Pendidikan. Bandung: Penerbit Alfabeta.

Copyright (C) 2020, Journal of Asian Multicultural Research for Economy and Management Study,

Under the license CC BY-SA 4.0 